\title{
Despite Similar Reduction of Blood Pressure and Renal ANG II and ET-1 Levels Aliskiren but not Losartan Normalizes Albuminuria in Hypertensive Ren-2 Rats
}

\author{
Z. VAŇOURKOVÁ ${ }^{1,2}$, H. J. KRAMER ${ }^{3}$, Z. HUSKOVÁ $^{1,2}$, L. ČERVENKA ${ }^{1,2,4}$, \\ I. VANĚČKOVÁ ${ }^{1,2}$
}

${ }^{1}$ Department for Experimental Medicine, Institute for Clinical and Experimental Medicine, Prague, Czech Republic, ${ }^{2}$ Cardiovascular Research Center, Institute for Clinical and Experimental Medicine, Prague, Czech Republic, ${ }^{3}$ Section of Nephrology, Medical Policlinic, Department of Medicine, University of Bonn, Germany, ${ }^{4}$ Department of Physiology, Second Faculty of Medicine, Charles University, Prague, Czech Republic

Received September 25, 2009

Accepted December 18, 2009

\section{Summary}

The relationship between angiotensin II (ANG II) and endothelin1 (ET-1) is known to be complex; both peptides can initiate and potentiate the gene expression of each other. This pilot study investigated the effects of the $\mathrm{AT}_{1}$ receptor blocker losartan or the direct renin inhibitor aliskiren on mean arterial pressure (MAP) and albuminuria and the renal ANG II and ET-1 levels. 3-month-old male Ren-2 transgenic rats (TGR) were treated either with losartan $\left(5 \mathrm{mg} \mathrm{kg}^{-1}\right.$ day $\left.^{-1}\right)$ or aliskiren $\left(10 \mathrm{mg} \mathrm{kg}^{-1}\right.$ day $\left.{ }^{1}\right)$ for 10 weeks. At the end of the experiment, rats were decapitated and cortical and papillary parts of kidneys were separated. Plasma and tissue ANG II levels were measured by RIA and tissue ET-1 concentrations by ELISA. In all four groups of animals ET-1 levels were lowest in renal cortex and more than 100 -fold higher in the papilla. Cortical and papillary ET-1 concentrations in untreated TGR significantly exceeded those of control HanSD rats and were significantly depressed by both drugs. In both strains, papillary ANG II concentrations were moderately but significantly higher than cortical ANG II, TGR exhibited higher ANG II levels both in cortex and papilla as compared to control HanSD rats. Aliskiren and losartan at the doses used depressed similarly the levels of ANG II in cortex and papilla and reduced ET-1 significantly in the renal cortex and papilla below control levels in HanSD rats. Albuminuria, which was more than twice as high in TGR as in HanSD rats, was normalized with aliskiren and reduced by $28 \%$ with losartan, although MAP was reduced to a similar degree by both drugs. Despite similar reductions of MAP and renal ET-1 and ANG II levels aliskiren appears to be more effective than losartan, at the doses used, in reducing albuminuria in heterozygous hypertensive Ren- 2 rats.

\section{Key words}

Ren-2 rats - Hypertension - Renin-angiotensin system • Endothelin system - RAS blockade - Aliskiren • Losartan • Albuminuria

\section{Corresponding author}

Ivana Vaneckova, Dept. of Experimental Hypertension, Institute of Physiology AS CR, Videnska 1083, CZ-142 20, Prague 4, Czech Republic. Fax: +420 24106 2488. E-mail: ivanava@biomed.cas.cz

\section{Introduction}

The renin-angiotensin (RAS) and endothelin (ET) systems are two of the most potent vasopressor systems with angiotensin II (ANG II) and endothelin-1 (ET-1) as the two most potent vasoconstrictors known to date (Pollock 2005). Their role in the development of hypertension and end-organ damage has been identified long time ago (Kobori et al. 2007, Schiffrin 2005). The crosstalk between the RAS and ET system has been documented for more than 15 years when ANG II has been shown to increase the expression of preproET-1 mRNA and the ET release in cultured endothelial cells 
(Imai et al. 1992). Moreover, it has been found that rats with chronic ANG II-dependent hypertension have elevated preproET mRNA and ET-1 peptide expression in renal tissues (Alexander et al. 2001, Barton et al. 1997, Sasser et al. 2002) and some of the effect of acutely administered ANG II are mediated by ET-1 (Riggleman et al. 2001). Different effect of ANG II infusion on ET-1 levels in distinct renal compartment (cortex and outer medulla versus inner medulla) has already been documented by Sasser et al. (2002). Furthermore, both in long-term (d'Uscio et al. 1997, Ortiz et al. 2001) and acute studies (Riggleman et al. 2001) the attenuation of ANG II-dependent hypertension by blockade of the ET system has been documented.

Recently, in type-I diabetic rat model BanesBerceli et al. (2007) have reported that ANG II and ET-1 share the same signaling pathway, namely the tyrosine Janus kinase 2 pathway. Moreover, chymase, which is involved in the transmural production of angiotensin II in the human heart, lungs and arteries, is also responsible for the hydrolysis of big-ET-1 (1-38) to an intermediate peptide ET-1 (1-31) (Orleans-Juste et al. 2008). Interestingly, it has been documented that levels of chymase, ET-1 (1-31), ANG II and ET-1 were enhanced in atherosclerosis (Kovanen 2007, Libbyand Shi 2007).

The kidney is a unique organ, in which all of the RAS components are present and therefore, local production of angiotensin II is possible through multiple independent mechanisms (Kumar and Boim 2009). Apart from the classic RAS pathway (Mitchell et al. 2007), local production of ANG II is mediated through prorenin receptors (Nguyen and Cotrepas 2008) and chymase (Durvasula and Shankland 2008). Additionally, circulating $\mathrm{ANG}$ II is internalized by an $\mathrm{AT}_{1}$ receptordependent mechanism (Ingert et al. 2002). As a result, ANG II concentration is much higher in the kidney than in the circulation. Equivocal results were obtained concerning ANG II levels in different kidney compartements showing either higher concentrations in the medulla (Navar et al. 1997, Pendergrass et al. 2006) or equivalent levels in cortex and medulla (Ingert et al. 2002) but no data on ANG II levels in papillary tissue are available.

Two types of RAS blocking agents have been selected due to their different sites of interference with the RAS cascade, losartan as a classic $\mathrm{AT}_{1}$ receptor blocker, blocking the $\mathrm{AT}_{1}$ receptor, and the direct renin inhibitor aliskiren, which blocks the RAS at the rate-limiting step, i.e. the conversion of angiotensinogen to angiotensin I.
Since the available experimental data show that the regulation of the renal ET system by ANG II may be an important factor in mediating the renal and hypertensive effects of ANG II, we were interested in the distribution of ANG II and ET-1 within the kidney and whether the blockade of the RAS at two different steps has different effects on the renal tissue content of ANG II and ET-1 and on the albuminuria as an indicator of renal damage.

\section{Materials and methods}

The present study was performed in accordance with guidelines and practices established by the Institute for Clinical and Experimental Medicine Animal Care and Use Committee (protocol 16/2008). All animals used in the study were housed in facilities accredited by the Czech Association of Laboratory Animal Care.

\section{Animals}

Male heterozygous transgenic rats [TGR; strain name TGR(mRen2)27] and normotensive Hannover Sprague-Dawley rats (HanSD rats) as their transgenenegative controls were housed at $25{ }^{\circ} \mathrm{C}$ under a $12 \mathrm{~h}$ light/dark cycle and had free access to chow (normal rat chow $-0.45 \% \mathrm{NaCl}$ ) and water. All animals used in this study were bred at the Center for Experimental Medicine of the Institute for Clinical and Experimental Medicine from stock animals supplied from Max Delbrück Center for Molecular Medicine in Berlin, Germany.

\section{Experimental design}

Studies were performed in 3-month-old male TGR and their transgene-negative controls (HanSD). Animals were treated either with losartan (5 mg kg${ }^{-1}$ day $^{-1}$, Sigma Aldrich) in drinking water, or with aliskiren (10 $\mathrm{mg} \mathrm{kg}^{-1} \mathrm{day}^{-1}$, Novartis USA) via SC osmotic minipumps (type M 2004 and M 2006, Alzet $\mathrm{Co}$ ) for 10 weeks. Blood pressure was measured with telemetry (TA11PA-C40, Data Sciences International, St. Paul, MN, USA). At the end of the experiment animals were decapitated, blood was collected and plasma was frozen and stored until assayed for ANG II concentration. Body weight, relative weights of kidney and heart, albuminuria, plasma and tissue ANG II (RIA) and tissue ET-1 (ELISA) concentrations were determined (Bäcker et al. 2001, Navar et al. 1994, Wakisaka et al. 1996) at the end of the experiment. Kidneys were rapidly removed, dissected into cortex and papilla, and 
Table 1. Albuminuria, mean arterial pressure (MAP), body weights and indices of KW/BW and HW/BW of individual experimental groups.

\begin{tabular}{lcccc}
\hline & HanSD & TGR & TGR + aliskiren & TGR + losartan \\
\hline$n$ & 6 & 8 & 8 & 8 \\
Albuminuria $(\mathrm{mg} / 24 \mathrm{~h})$ & $10.5 \pm 2.9$ & $22.8 \pm 3.5^{*}$ & $12.2 \pm 1.2^{\#}$ & $16.5 \pm 1.9$ \\
MAP $($ mmHg) & $128 \pm 3$ & $162 \pm 5^{*}$ & $125 \pm 3$ & $126 \pm 2$ \\
Body weight $(\mathrm{g})$ & $551 \pm 12$ & $558 \pm 10$ & $550 \pm 8$ & $565 \pm 7$ \\
KW/BW $(\mathrm{mg} / \mathrm{g})$ & $2.84 \pm 0.03$ & $2.87 \pm 0.02$ & $2.85 \pm 0.03$ & $2.81 \pm 0.04$ \\
HW/BW $(\mathrm{mg} / \mathrm{g})$ & $2.64 \pm 0.02$ & $2.93 \pm 0.1^{*}$ & $2.70 \pm 0.03$ & $2.59 \pm 0.04$ \\
\hline
\end{tabular}

Values are means \pm SEM. HanSD - transgene-negative rats; TGR - Ren-2 transgenic rats; MAP - mean arterial pressure; BW - body weight; HW - heart weight; KW - kidney weight. ${ }^{*} \mathrm{P}<0.05$ compared with unmarked value, ${ }^{\#} \mathrm{P}<0.05$ aliskiren vs. losartan-treated TGR

homogenized in pure methanol. For ANG II determination, homogenates were centrifuged at $3,000 \mathrm{~g}$ and evaporated under nitrogen to dryness. Samples were reconstituted by a phosphate buffer and extracted by BondElut PH columns (Euro-Diagnostica, Hamburg, Germany). For ET-1 determinations approximately 300$400 \mathrm{mg}$ cortical and $200 \mathrm{mg}$ papillary tissues were homogenized with $1 \mathrm{M}$ ethanol and $20 \mathrm{mM}$ TFA solution, boiled for $10 \mathrm{~min}$, centrifuged at 10,000 $\mathrm{g}$ and extracted by Sep-Pak C18 columns. Collected supernatants were dried in a speed-vac, reconstituted with $0.1 \mathrm{ml}$ of a solution (0.1\% TFA in DMSO) and assayed in duplicate using an ELISA kit as described by manufacturer (Immuno-Biological Laboratories, Japan). The kit exhibits cross reactivity with other ET-1 peptides as follows: $0.1 \%$ for ET-3 and less than $0.1 \%$ for ET-1 (131), ET-2 (1-31), human big ET-1 and rat big ET-1.

ET-1 concentration was related to wet weight (pg/g tissue).

\section{Results}

MAP, body and organ weights, histology, and albuminuria

As seen in Table 1, at the end of the study untreated TGR were markedly hypertensive (MAP 162 \pm 5 vs. $128 \pm 3 \mathrm{~mm} \mathrm{Hg}$ in control HanSD rats, $\mathrm{p}<0.05)$. Treatment with either aliskiren or losartan normalized BP $(125 \pm 3$ and $126 \pm 2 \mathrm{~mm} \mathrm{Hg}$, respectively, $\mathrm{p}<0.05)$. No differences in body weights and relative kidney and heart weights were observed among the four groups of animals after 10 weeks of the study. Morphological changes in renal parenchyma corresponded to focal segmental glomerulosclerosis. Ultrastucturaly, advanced degenerative changes of podocytes were found in untreated
TGR. Aliskiren and losartan similarly restored podocyte morphology.

Albuminuria of untreated TGR was significantly higher in comparison with control HanSD. While losartan only partly reduced albuminuria by $28 \%$, aliskiren normalized it to that of control HanSD rats.

\section{Renal ANG II and ET-1 concentrations}

Cortical and papillary ANG II concentrations (Fig. 1) in untreated TGR significantly exceeded those of control HanSD rats and papillary ANG II levels were significantly higher than cortical ANG II levels. Both losartan and aliskiren depressed ANG II concentrations.

Cortical ET-1 levels were moderately and papillary ET-1 levels were strongly increased in untreated TGR as compared to HanSD rats as controls. ET-1 concentrations were highest in the renal papilla and were more than hundred-fold higher than in the renal cortex. ET-1 levels were significantly decreased in cortex and papilla to a similar degree by losartan and aliskiren.

\section{Plasma ANG II concentrations}

Plasma ANG II (Fig. 2) was significantly higher in untreated TGR as compared to HanSD rats $(p<0.05)$. As expected, losartan further increased plasma ANG II level, while aliskiren reduced its level to that of controls.

\section{Discussion}

Our study has shown that BP was similarly reduced with both drugs in heterozygous Ren-2 transgenic rats. They had also comparable effect on organ protection, i.e. they prevented the rise in heart weight as an index of cardiac hypertrophy and attenuated the increase in renal albumin excretion. Similar results were 


\section{A}

Cortex

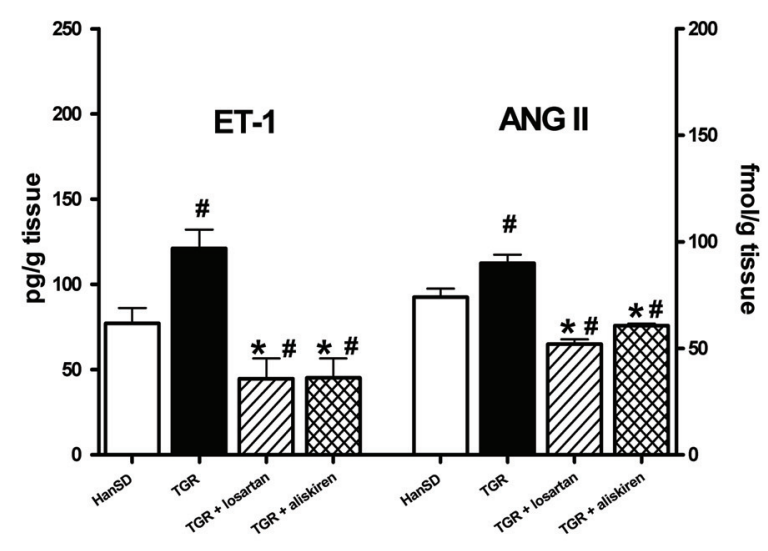

B

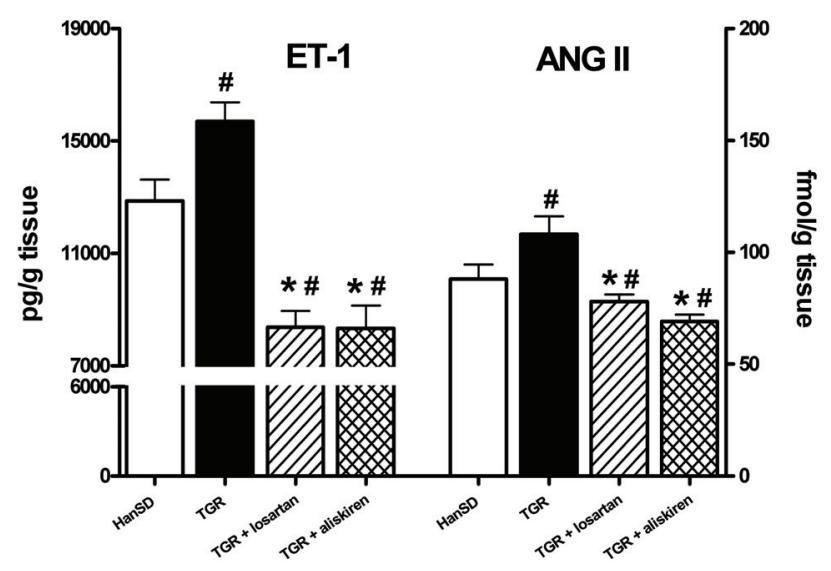

Fig 1. Cortical (A) and papillary (B) endothelin-1 and angiotensin II concentrations. \# $\mathrm{p}<0.05$ versus HanSD, $* p<0.05$ vs. untreated TGR

achieved also in human studies-AVOID (Parving et al. 2008) evaluating proteinuria in diabetic patients and ALLAY (Solomon et al. 2009) studying patients with cardiac hypertrophy. The latter study has shown that either monotherapy or combination therapy resulted in similar regression of cardiac hypertrophy. However, our present study has shown better antialbuminuric effect of aliskiren versus losartan and similarly, we have also demonstrated a stronger antiproteinuric effect achieved with aliskiren than with losartan in another experiment with adult TGR (Rakušan et al., data to be published). The greater beneficial effect of aliskiren over losartan might be related to the fact that aliskiren decreases (pro)renin receptor gene expression as has been shown by Feldman et al. (2008). On the other hand, it has been shown that $\mathrm{AT}_{1}$ receptor blockade (at the dose that did not change blood pressure) had positive effect on the reappearance of foot processes of podocytes - the

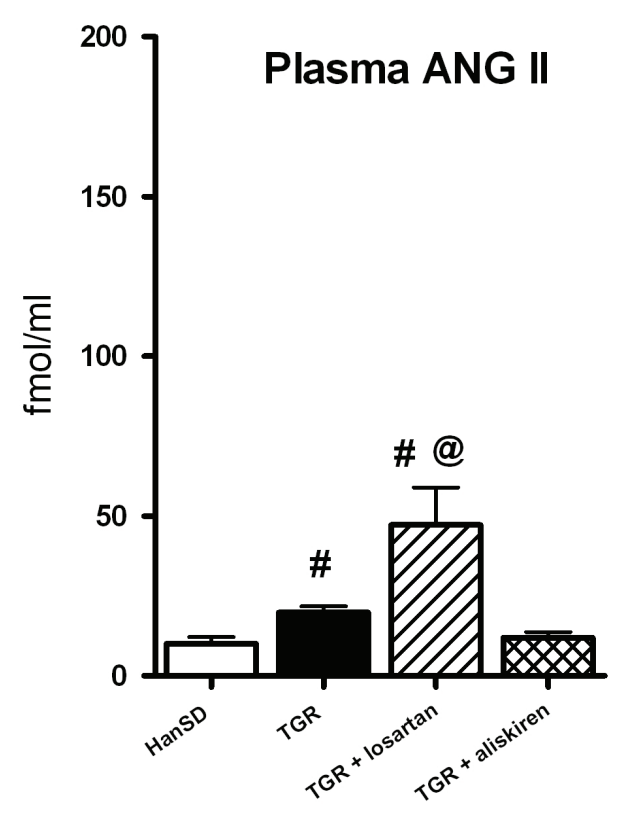

Fig 2. Plasma angiotensin II concentrations. \# $p<0.05$ versus HanSD, @ p $<0.05$ vs. aliskiren treated TGR

filtration barrier to the kidney, and also on the reexpression of proteins specific of podocyte cells, such as nephrin, podocin, E-cadherin and megalin (Huby et al. 2009). The precise mechanisms responsible for the major antiproteinuric and antialbuminuric effects of aliskiren, therefore, need further investigations.

Our present results confirm previous findings (Girchev et al. 2004, Girchev et al. 2006) that ET-1 levels are approximately 100 -fold higher in the renal papilla than in the renal cortex, where they are moderately higher in TGR than in control HanSD rats. Tissue ET-1 levels decreased after RAS blockade with losartan and aliskiren in the renal cortex and papilla in a similar manner as found for tissue ANG II levels.

As expected, the $\mathrm{AT}_{1}$ receptor blocker losartan increased circulating ANG II levels as compared with untreated TGR, probably by displacement of ANG II from its receptor (Campbell et al. 1995, Ingert et al. 2002). ANG II levels in the renal cortex were slightly lower than in papillary tissue in both strains but ANG II levels in the cortex of TGR was higher than that in HanSD rats. This is compatible with the results of Pendergrass et al. (2006) who found increased medullary and cortical ANG II levels in the congenic mRen2.Lewis strain [established from the backcross of the (mRen2)27 transgenic strain] but is not compatible with the results of Ingert et al. (2002) in Wistar-Kyoto rats. Losartan treatment depressed cortical and papillary ANG II levels by $50 \%$ in untreated TGR as a result of displacement of ANG II from the $\mathrm{AT}_{1}$ receptor, whereas following 
aliskiren treatment the lower ANG II tissue level probably resulted from the reduction of intrarenal ANG I production. Although lower tissue ANG II concentrations would be anticipated in aliskiren-treated rats, both drugs induced comparable depression of renal ANG II levels. In fact, significantly lower ANG II concentrations were found in young aliskiren-treated TGR as compared with losartan-treated animals (Rakušan et al., data to be published), but these results were not confirmed in adult animals and thus await further evaluations.

In the present study we did not measure plasma ET-1 concentration since ET-1 is known to act as a paracrine/autocrine agent rather than as a circulating hormone. Therefore, its level in plasma is not predictive of either its local action or its influence on ANG II levels. In agreement with the results obtained in spontaneously hypertensive rats (Girchev et al. 2004) and in adult heterozygous TGR (Vernerová et al. 2008, Vernerová et al. 2009) we found higher cortical ET-1 levels in TGR than in HanSD rats. However, in contrast to the Prague hypertensive rat (PHR) (Vogel et al. 1999) and the spontaneously hypertensive rat (SHR) (Girchev et al. 2004), in which lower papillary ET-1 content was found, ET-1 levels in both the cortex and the papilla of TGR significantly exceeded those of control rats. One possible explanation for these discrepant results might be related to the different origin of these strains, SHR and PHR being derived from Wistar, while TGR from SpragueDawley rats. Papillary ET-1 concentrations exceeded hundred-fold those of cortical levels, a finding that is in agreement with previous observations (Girchev et al. 2004, Girchev et al. 2006). Although a high density of binding sites for ET in the papilla has previously been described (Woodcockand Land. 1991), the physiological significance of such abundant quantities of ET-1 in the renal papilla is not fully understood since the main effect of ET-1 on the modulation of renal hemodynamics and excretory function was originally ascribed to the medullary portion of the kidney, where, in addition, the $\mathrm{ET}_{\mathrm{B}}$ receptors exert their clearance function (Brunner et al. 2006). For a precise explanation of the respective role of ET-1 in the kidney further investigations, including measurements of urinary ET-1 excretion and the distribution of $\mathrm{ET}_{\mathrm{A}}$ and $\mathrm{ET}_{\mathrm{B}}$ receptors, are required.

In agreement with the fact that ANG II and ET-1 were found to share the same signaling pathway, our results showed a positive correlation between cortical and papillary ET-1 and ANG II levels in control HanSD rats and in untreated as well as treated TGR. Zhuo et al. (1998) found that ET-1 and ANG II receptors overlap in renomedullary interstitial cells of the inner medullary stripe and the papilla suggesting some mutual relationship between effects of the two vasoconstrictors but the precise mechanisms need to be further clarified.

In conclusion, the treatment with the $\mathrm{AT}_{1}$ blocker and the direct renin inhibitor affects renal tissue ANG II and ET-1, which share the same signaling pathway, in a similar direction in both renal cortex and papilla. Our most important finding shows that despite similar reductions in MAP and renal ET-1 and ANG II levels aliskiren appears to be more effective than losartan, in the doses used, in reducing albuminuria in heterozygous hypertensive Ren-2 rats.

\section{Conflict of Interest}

There is no conflict of interest.

\section{Acknowledgements}

I.V. is supported by the institutional financial support of the Institute for Clinical and Experimental Medicine (MZ 00023001) and the Czech Science Foundation (grants Nr. 305/07/0167 and 305/07/J004). H.J.K. is supported by the German Research Foundation (DFG, Deutsche Forschungsgemeinschaft; grants No. 433/14-2 and 436 TSE 113/50, 113/56 and 113/57/0-1) and the German Academic Exchange Service (DAAD). Portions of this work were performed during the stay of Z.V. as a visiting scientist at the University of Bonn, which was supported by a grant from the Deutsche Forschungsgemeinschaft, Bonn (grants No. 433/14-2). Czech Science Foundation supported also Z.H. (grant Nr. 305/08/P053) and L. ̌́. (grant Nr. 305/08/J006).

\section{References}

ALEXANDER BT, COCKRELL KL, RINEWALT AN, HERRINGTON JN, GRANGER JP: Enhanced renal expression of preproendothelin mRNA during chronic angiotensin II hypertension. Am J Physiol 280: R1388R1392, 2001.

BÄCKER A, BOKEMEYER D, KRAMER HJ: Endothelin synthesis and receptors in porcine kidney. Acta Physiol Scand 171: 105-112, 2001. 
BANES-BERCELI AK, KETSAWATSOMKRON P, OGBI S, PATEL B, POLLOCK DM, MARRERO MB. Angiotensin II and endothelin-1 augment the vascular complications of diabetes via JAK2 activation. Am J Physiol 293: H1291-H1299, 2007.

BARTON M, SHAW S, D'USCIO LV, MOREAU P, LÜSCHER TF: Angiotensin II increases vascular and renal endothelin-1 and functional endothelin converting enzyme activity in vivo: role of ETA receptors for endothelin regulation. Biochem Biophys Res Commun 238: 861-865, 1997.

BRUNNER F, BRAS-SILVA C, CERDEIRA AS, LEITE-MOREIRA AF: Cardiovascular endothelins: essential regulators of cardiovascular homeostasis. Pharmacol Ther 111: 508-531, 2006.

CAMPBELL DJ, KLADIS A, VALENTIJN AJ: Effects of losartan on angiotensin and bradykinin peptides and angiotensin-converting enzyme. J Cardiovasc Pharmacol 26: 233-240, 1995.

D'USCIO LV, MOREAU P, SHAW S, TAKASE H, BARTON M, LÜSCHER TF: Effects of Chronic ETA-receptor blockade in angiotensin II-induced hypertension. Hypertension 29: 435-441, 1997.

DURVASULA RV, SHANKLAND SJ: Activation of a local renin angiotensin system in podocytes by glucose. Am $J$ Physiol 294: F830-F839, 2008.

FELDMAN DL, JIN L, XUAN H, CONTREPAS A, ZHOU Y, WEBB RL, MUELLER DN, FELDT S, CUMIN F, MANIARA W, PERSOHN E, SCHUETZ H, JAN DANSER AH, NGUYEN G: Effects of aliskiren on blood pressure, albuminuria, and (pro)renin receptor expression in diabetic TG(mRen-2)27 rats. Hypertension 52: 130-136, 2008.

GIRCHEV R, BÄCKER A, MARKOVA P, KRAMER HJ: Impaired response of the denervated kidney to endothelin receptor blockade in normotensive and spontaneously hypertensive rats. Kidney Int 65: 982-989, 2004.

GIRCHEV R, BÄCKER A, MARKOVA P, KRAMER HJ: Renal endothelin system and excretory function in WistarKyoto and Long-Evans rats. Acta Physiol (Oxf) 186: 67-76, 2006.

HUBY AC, RASTALDI MP, CARON K, SMITHIES O, DUSSAULE JC, CHATZIANTONIOU C: Restoration of podocyte structure and improvement of chronic renal disease in transgenic mice overexpressing renin. PLoS One 4: e6721, 2009.

IMAI T, HIRATA Y, EMORI T, YANAGISAWA M, MASAKI T, MARUMO F: Induction of endothelin-1 gene by angiotensin and vasopressin in endothelial cells. Hypertension 19: 753-757, 1992.

INGERT C, GRIMA M, COQUARD C, BARTHELMEBS M, IMBS JL: Contribution of angiotensin II internalization to intrarenal angiotensin II levels in rats. Am J Physiol 283: F1003-F1010, 2002.

KOBORI H, NANGAKU M, NAVAR LG, NISHIYAMA A: The intrarenal renin-angiotensin system: from physiology to the pathobiology of hypertension and kidney disease. Pharmacol Rev 59: 251-287, 2007.

KOVANEN PT: Mast cells: multipotent local effector cells in atherothrombosis. Immunol Rev 217: 105-122, 2007.

KUMAR R, BOIM MA: Diversity of pathways for intracellular angiotensin II synthesis. Curr Opin Nephrol Hypertens 18: 33-39, 2009.

LIBBY P, SHI GP: Mast cells as mediators and modulators of atherogenesis. Circulation 115: 2471-2473, 2007.

MITCHELL KD, BOTROS FT, NAVAR LG: Intrarenal renin-angiotensin system and counteracting protective mechanisms in angiotensin II-dependent hypertension. Acta Physiol Hung 94: 31-48, 2007.

NAVAR LG, LEWIS L, HYMEL A, BRAAM B, MITCHELL KD: Tubular fluid concentrations and kidney contents of angiotensins I and II in anesthetized rats. J Am Soc Nephrol 5: 1153-1158, 1994.

NAVAR LG, IMIG JD, ZOU L, WANG CT: Intrarenal production of angiotensin II. Semin Nephrol 17: 412-422, 1997.

NGUYEN G, CONTREPAS A: The (pro)renin receptors. J Mol Med 86: 643-646, 2008.

ORLEANS-JUSTE P, HOUDE M, RAE GA, BKAILY G, CARRIER E, SIMARD E: Endothelin-1 (1-31): from chymase-dependent synthesis to cardiovascular pathologies. Vascul Pharmacol 49: 51-62, 2008.

ORTIZ MC, SANABRIA E, MANRIQUEZ MC, ROMERO JC, JUNCOS LA: Role of endothelin and isoprostanes in slow pressor responses to angiotensin II. Hypertension 37: 505-510, 2001.

PARVING HH, PERSSON F, LEWIS JB, LEWIS EJ, HOLLENBERG NK: Aliskiren combined with losartan in type 2 diabetes and nephropathy. $N$ Engl $J$ Med 358: 2433-2446, 2008.

PENDERGRASS KD, AVERILL DB, FERRARIO CM, DIZ DI, CHAPPELL MC: Differential expression of nuclear $\mathrm{AT}_{1}$ receptors and angiotensin II within the kidney of the male congenic mRen2.Lewis rat. Am J Physiol 290: F1497-F1506, 2006. 
POLLOCK DM: Endothelin, angiotensin, and oxidative stress in hypertension. Hypertension 45: 477-480, 2005.

RAKUŠAN D, KUJAL P, KRAMER H, HUSKOVÁ Z, VAŇOURKOVÁ Z, VERNEROVÁ Z, MRÁZOVÁ I, THUMOVÁ M, ČERVENKA L, VANĚČKOVÁ I: Durable antihypertensive effect of aliskiren is accompanied by reduced proteinuria and normalization of glomerular area. Am J Physiol (submitted).

RIGGLEMAN A, HARVEY J, BAYLIS C: Endothelin mediates some of the renal actions of acutely administered angiotensin II. Hypertension 38: 105-109, 2001.

SASSER JM, POLLOCK JS, POLLOCK DM: Renal endothelin in chronic angiotensin II hypertension. Am J Physiol 283: R243-R248, 2002.

SCHIFFRIN EL: Vascular endothelin in hypertension. Vascul Pharmacol 43: 19-29, 2005.

SOLOMON SD, APPELBAUM E, MANNING WJ, VERMA A, BERGLUND T, LUKASHEVICH V, CHERIF PC, SMITH BA, DAHLOF B: Effect of the direct renin inhibitor aliskiren, the angiotensin receptor blocker losartan, or both on left ventricular mass in patients with hypertension and left ventricular hypertrophy. Circulation 119: 530-537, 2009.

VERNEROVÁ Z, KRAMER HJ, BÄCKER A, ČERVENKA L, OPOČENSKÝ M, HUSKOVÁ Z, VAŇOURKOVÁ Z, EIS V, CHÁBOVÁ ČERTÍKOVÁ V, TESǍ̌ V, MALÝ J, VANĚČKOVÁ I: End-organ damage in in hypertensive heterozygous Ren-2 rats: influence of early and late endothelin receptor blockade. Physiol Res $\mathbf{5 8}$ (Suppl 2): S69-S78, 2009.

VERNEROVÁ Z, KUJAL P, KRAMER HJ, BÄCKER A, ČERVENKA L, VANĚČKOVÁ I: Late-onset endothelin receptor blockade in hypertensive heterozygous REN-2 transgenic rats. Vascul Pharmacol 48: 165-173, 2008.

VOGEL V, BÄCKER A, HELLER J, KRAMER HJ: The renal endothelin system in the Prague hypertensive rat, a new model of spontaneous hypertension. Clin Sci (Lond) 97: 91-98, 1999.

WAKISAKA N, KUBOTA T, ANDO K, AIHARA M, INOUE H, ISHIDA H: Endothelin-1 kinetics in plasma, urine, and blister fluid in burn patients. Ann Plast Surg 37: 305-309, 1996.

WOODCOCK EA, LAND S: Endothelin receptors in rat renal papilla with a high affinity for endothelin-3. Eur $J$ Pharmacol 208: 255-260, 1991.

ZHUO J, DEAN R, MARIC C, ALDRED PG, HARRIS P, ALCORN D, MENDELSOHN FA: Localization and interactions of vasoactive peptide receptors in renomedullary interstitial cells of the kidney. Kidney Int Suppl 67: S22-S28, 1998. 